\title{
ПЕРСПЕКТИВНІСТЬ ВИКОРИСТАННЯ ГОЛОЗЕРНОГО ВІВСА В ДІЄТИЧНИХ ПРОДУКТАХ БЕЗ ГЛЮТЕНУ. ЕКСПЕРИМЕНТАЛЬНЕ ДОСЛІДЖЕННЯ ЗМІНИ СТРУКТУРИ ЗЕРНА В ПРОЦЕСІ ЕКСТРУЗІЙНОЇ ОБРОБКИ
}

\author{
Іваницький Г.К. д-р. техн. наук, Целень Б.Я. канд. техн. наук, с.н.с., \\ Ганзенко В.В. канд. техн. наук, с.н.с, Радченко Н.Л. канд. техн. наук, с.н.с. \\ Інститут технічної теплофізики НАНУ, м. Київ
}

\begin{abstract}
Проведено аналіз світового і вітчизняного ринку виробництва безглютенових продуктів та встановлено перспективність изього напрямку через щьорічне зростання кількості населення, яке нездатне засвоювати білок глютену. В Украӥні власне виробництво безглютенових продуктів ще досить обмежене $і$ основний асортимент продукиї представлений імпортними виробниками. В рамках иього було окреслено основні проблеми та сформульовано завдання, які полягають у необхідності нарощування обсягів власного виробництва за рахунок пошуку нових видів сировини, оновлення рещептур та розроблення новітніх технологій обробки. Для вирішення цих завдань було проаналізовано різні види сировини з яких запропоновано використовувати голозерний овес як основу складу сухих дієтичних безглютенових сумішей. Для його обробки було запропоновано використовувати екструдер, оскільки він дозволяє за рахунок регулювання початкової вологи в зерні змінювати тиск, температуру прочесу та час обробки, забезпечуючи при изьому необхідну мікроструктуру екструдату і високі якісні показники. Крім иьього, під час екструзії відбувається знешкодження шкідлиої мікрофлори і видалення надлишкової вологи, що дозволить збільшити термін зберігання сухої суміші і покращитти якість змішування компонентів. Експериментальна частина досліджень полягала у визначенні доцільності використання екструдера для обробки голозерного вівса при отриманні сухих сумішей. Для ичього експериментальним шляхом було встановлено механізм впливу екструзії на мікроструктуру зерна при різних режимах обробки та проведено порівняння екструдату зі зразками не обробленого зерна, а також проаналізовано динаміку структурних перетворень, які відбуваються в каналі екструдера. Проведено оцінку кількості залишкової вологи в отриманому екструдаті для визначення терміну зберігання сухих сумішей та параметрів змімування з іншими компонентами. Доведено дочільність використання в подальшому екструдера для обробки голозерного вівса при отриманні сухих сумімей.
\end{abstract}

Ключові слова: голозерний овес, безглютенові продукти, екструзійні технології, екструдер.

Вступ Світовий ринок безглютенових продуктів за останні роки показав стрімке зростання та досяг в 2020 році 6,2 млрд. доларів, шо на $65 \%$ перевищує показники 2012 року. Надалі експерти прогнозують щорічне зростання цього показника на 7 \%. Аналіз вітчизняного ринку дієтичного харчування показав також щорічне стійке зростання попиту на продукти безглютенової групи. При цьому спостерігається їх періодичний дефіцит через залежність від імпортерів та обмежений асортимент продукції вітчизняних виробників. Такий попит пов'язаний із загальною світовою тенденцією зростання на $1 \%$ числа населення 3 генетичною схильністю до непереносимості глютену (целіакією), а також збільшенням до 7-15 \% кількості людей, які не засвоюють білок глютену без целіакії або ж мають алергічну реакцію на пшеницю, жито, ячмінь, овес плівчастий (0,2 \%) [1,2]. В Україні ця цифра офіційно становить 0,05 \% населення [2, 3], однак в дійсності ці показники значно занижені. Споживачами безглютенових продуктів переважно $є$ діти, молодь та люди середнього віку. Серед продуктів, які найбільше користуються попитом: безглютенові батончики, печиво, хлібобулочні вироби та різноманітні напої. Також розповсюджені різні види борошна та їх сумішей, зокрема, пшона, зеленої гречки, кукурудзи, коричневого рису, сорго, кунжуту тощо. Переважна більшість наведених продуктів імпортується з Німеччини (“Glutano”), Італії (“dr. Schar”), Іспанії (“Gullon”), Польщі (“Bezgluten”) та мають доволі високу вартість. Обсяг вітчизняного виробництва досить обмежений і представлений наразі лише кількома компаніями, такими, наприклад, як “Каскад”, що випускає сировину і готові продукти, "Healthy Tradition", яка реалізує лише готову продукцію та "Rich-Oil", що випускає тільки сировину [2]. У зв’язку з ситуацією, що склалася на сьогодні в Україні з цього питання, актуальним завданням стає нарощування обсягів власного виробництва безглютенових продуктів за рахунок пошуку нових видів сировини, оновлення рецептур та розроблення новітніх технологій обробки.

Аналіз останніх досліджень. Проаналізувавши ринок сировини за останні роки, варто окремо виділити голозерний овес [3-11]. Обсяги його вирощування в світі щорічно стабільно зростають. Серед десяти видів здорової їжі він, за даними журналу "Тіме", займає п'яте місце [10]. Для України це досить новий мало 
досліджений вид сировини. Особливу цінність він представляє для виробництва безглютенових продуктів завдяки відсутності у своєму складі білку глютену. Окрім цього, він характеризується підвищеним вмістом білків (14,3-19,5 \%), жирів (4,6-4,67 \%), невеликою кількістю клітковини (4 \%) та малою зольністю (2,5 \%) у порівнянні з традиційним плівчастим зерном вівса $[5,8,11,12]$. 3 точки зору переробки він також економічно вигідний, оскільки, в структурі зерна відсутні зовнішня оболонка та характерні волоски на поверхні зерна, наявність яких у плівчастих сортах вівса знижує вихід готового продукту до 53 \% [3-5, 8,9]. Голозерний овес може використовуватися для продовольчих цілей без попередньої доробки, що значно знижує час обробки, трудові витрати і вартість виробництва.

На сьогоднішній день вітчизняне виробництво переробляє голозерний овес переважно на крупу, муку, рідше на толокно $[3,5,7,12,13]$. Такі обсяги недостатні для внутрішнього ринку виробництва безглютенових продуктів. Їх потенційне збільшення дозволило би значно розширити спектр продукції, зокрема, виробляти вівсяне молоко, напої з різноманітними добавками, печиво, батончики, вершки, хлібобулочні вироби і т. п. Невеликі обсяги переробки голозерного вівса пояснюються необхідністю перебудови традиційних вітчизняних технологій переробки плівчастого вівса та їх переорієнтації на обробку голозерного, зважаючи на суттєву відмінність анатомічної і морфологічної будови цих сортів. В Україні на сьогоднішній день відсутній регламент переробки голозерних сортів вівса, а його переробка проводиться по нормативній і технічній документації або за технічними умовами для плівчастих сортів вівса [13]. Тому для вирішення цієї проблеми необхідна достатня експериментально-дослідна база та обгрунтовані рекомендації щодо особливостей ведення процесу, заходи по розробці нормативної документації і наступної модернізації обладнання та технологічних ліній в цілому.

В Одеській національній академії харчових технологій на протязі років послідовно проводяться дослідження, спрямовані на створення схем переробки голозерного вівса в крупи з використанням холодного і гарячого кондиціонування зерна [7-9,13]. Розроблена схема включає наступні етапи: очистку зерна від домішок, холодне кондиціонування, шліфування, сортування продуктів шліфування, гаряче кондиціонування з наступним контролем продукції. Пропоноване рішення дозволяє скоротити частку дробленого в результаті шліфування зерна в 1,5-2 рази.

В Білорусі проводяться роботи присвячені розробці нових енергозберігаючих технологій виробництва круп і пластівців з голозерного вівса. Авторами запропоновано дві схеми: 1 - розділення голозерного вівса на дві фракції з наступним лущенням лише однієї; 2 - без розділення на фракції і виключення етапу лущення [11].

Застосування екструзійних технологій. На основі аналізу існуючих вітчизняних i зарубіжних технологій та літературних даних останніх років було встановлено, що для отримання безглютенових сухих сумішей на основі голозерного вівса найбільше підходить екструзійна обробка [1,6,11,14-21]. Застосування екструдера дозволяє за рахунок регулювання початкової вологи в зерні змінювати тиск, температуру процесу та час обробки, забезпечуючи необхідну мікроструктуру екструдату, властивості і фізико-хімічний склад. Крім цього, під час екструзії відбувається знешкодження шкідливої мікрофлори і видалення надлишкової вологи, що дає можливість подовжити термін зберігання сухої суміші.

В Росії активно проводяться наукові дослідження по розробці технологій переробки плівчастих та голозерних сортів ячменю і вівса на муку [4,14-17]. Серед нових розробок варто відмітити технологію отримання муки з використанням екструзійного способу обробки [14]. В даній роботі дослідження проводилися 3 метою підвищення харчової цінності хлібобулочної продукції за рахунок введення в рецептуру муки із плівчастих та голозерних сортів ячменю і вівса. Запропоновано екструзійну технологію та режими ведення процесу, а також рекомендовано рецептуру з додаванням до 10 \% сумішей екструдованої муки до складу хлібобулочних виробів. В роботі [18] ведуться дослідження по розробці екструзійної технології виробництва сиропів з голозерного вівса, зокрема, в якості лікувального безглютенового продукту, рекомендованого для хворих целіакією, а також для застосування в кондитерській галузі.

В Японії впроваджується виробництво хліба на основі голозерного вівса [19]. Виробники невеликих пекарень запропонували адаптувати екструзійну технологію виробництва глазурованих кондитерських виробів для виробництва безглютенового хліба основним компонентом якого $є$ голозерний овес. Технологія побудована на основі коекструдера серії KN компанії "Rheon” [1].

Застосування екструзійних технологій при виробництві харчових продуктів забезпечує глибокі біохімічні перетворення вуглеводів, клітковини та білків, що сприяє підвищенню їх засвоюваності і отримання екструдатів хорошої якості. Асортимент харчової продукції, що виробляється за допомогою екструзійної технології, включає більше 400 найменувань. Тільки в США виробляється продуктів типу готових сніданків на понад 2 млрд доларів, причому їх випуск зростає щорічно на 3 \% [1]. В Німеччині обсяг споживання екструдованих зернових продуктів збільшився з 1991 по 2001 рік на 50 \% [10].

Формулювання мети та постановка завдання. Дана робота проводилась з метою експериментального дослідження зміни мікроструктури голозерного вівса в процесі екструзійної обробки стосовно розробки на його основі сухих гомогенізованих безглютенових сумішей $з$ наступним додаванням сухих молочних концентратів - для потреб харчової промисловості.

Для досягнення поставленої мети на першому етапі досліджень поставлено наступні завдання:

Наукові праці, Том 85, випуск 1 
- Вивчити механізм впливу екструзії на мікроструктуру голозерного вівса при різних режимах обробки.

- Дослідити динаміку структурних перетворень зернової сировини в каналі екструдера.

- Порівняти структуру екструдату із структурою суцільного зерна в залежності від режимів обробки.

- Визначити залишкову вологу в отриманому екструдаті для подальшого визначення терміну зберігання сухих сумішей та параметрів змішування з іншими компонентами.

Проведення експериментальних досліджень. Дослідження по вивченню механізму впливу екструзії на мікроструктуру голозерного вівса проводились на лабораторному стенді, основою якого є екструдер ПЕК 40х5В з продуктивністю 30-40кг/год. Схема лабораторного стенду та фотографія стенду представлені, відповідно, на рисунках 1а та 1б. Для досліджень використовувався голозерний овес сорту “Самуэль” 3 великим вмістом білку (15,72\%) та жиру (4,86 \%) [12]. Експерименти проводились при різних режимах обробки, зокрема, при зміні початкового вологовмісту зерна, температури процесу та часу обробки. Режими екструзії обрано на основі рекомендацій, наведених в роботі [14], а саме: температура в каналі для першого експерименту $-150{ }^{\circ} \mathrm{C}$, для другого $-160^{\circ} \mathrm{C}$, час обробки від 6 до 10 с в залежності від заданої температури. Початковий вміст вологи в зерні підібрано для першого експерименту - 10 \% (при температурі екструзії $\left.160{ }^{\circ} \mathrm{C}\right)$, для другого $-11,8 \%$ (при $150{ }^{\circ} \mathrm{C}$ ).

В ході першого експерименту попередньо зволожене до заданих значень (10 \%) зерно подавалось в бункер, звідки дозатором рівномірно надходило в завантажувальну воронку екструдера для обробки (рис.1а). В каналі екструдера за рахунок обертання шнека зерно поступово подрібнювалось і переміщувалось вздовж каналу до виходу з фільєри. Максимальні значення тиску та температури в каналі екструдера досягаються перед фільєрою, а тому основні структурні перетворення відбуваються перед виходом 3 екструдера [22]. Після продавлювання через профілюючий інструмент (фільєру) з екструдера виходить спучений стренг, що має форму джгута.

Аналогічно проводився другий експеримент з початковим вологовмістом в сировині - 11,8 \% та температурою екструзії $-150{ }^{\circ} \mathrm{C}$.

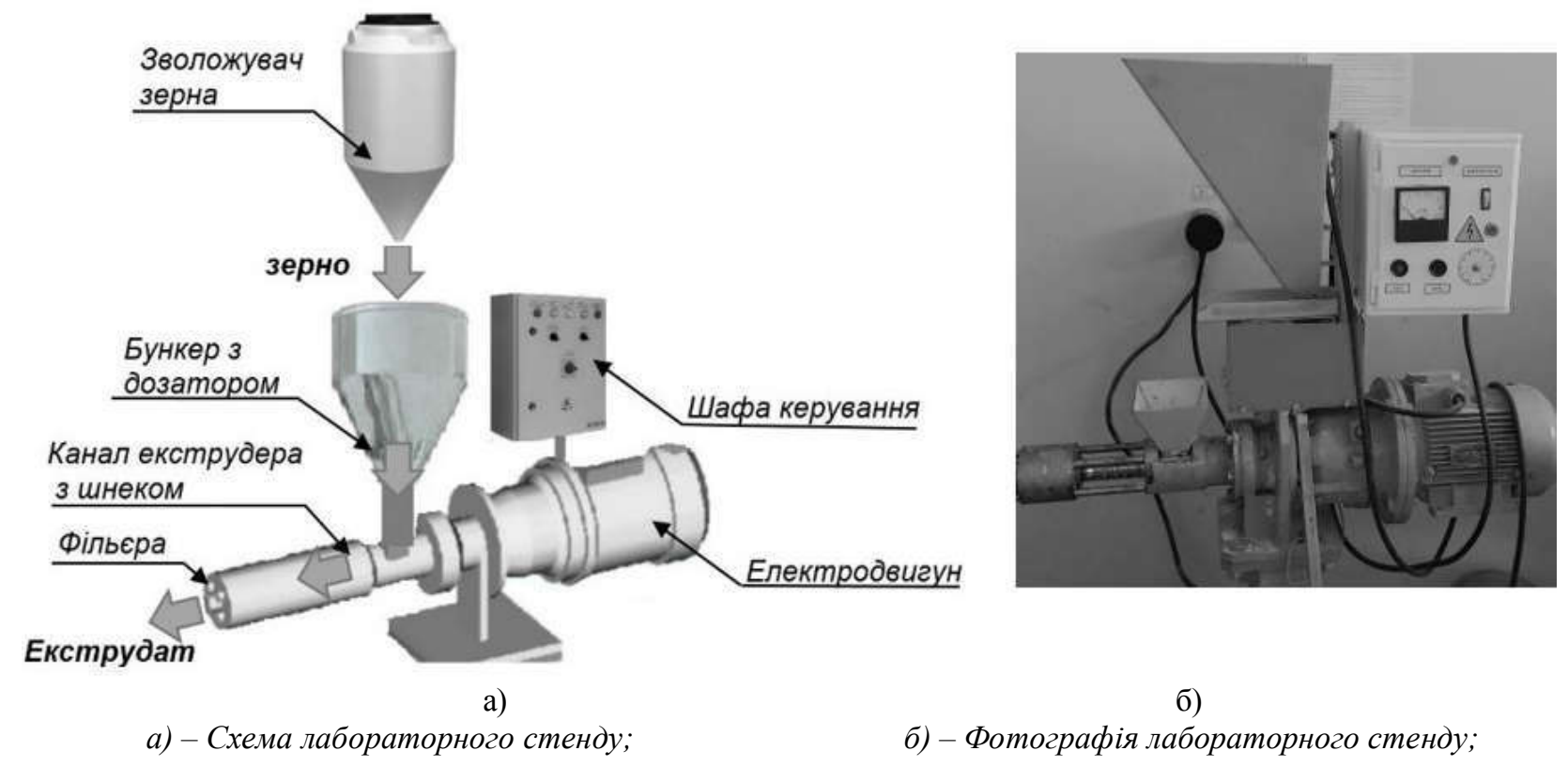

Рис. 1 - Лабораторний стенд для обробки голозерного вівса

В обох експериментах відбір проб зразків зерна проводився тричі: до обробки в екструдері, з каналу екструдера перед фільєрою та на виході 3 фільєри. Дослідження мікроструктури зразків проводились на мікроскопі Zeiss - Axio Imager за методом диференційно-інтерференційного контрасту (при х40).

Аналіз результатів. Для дослідження динаміки структурних перетворень в каналі екструдера необхідно спочатку проаналізувати структуру зерна до обробки. Тому було вивчено зразок поверхні ядра необробленого зерна голозерного вівса (рис.2а). Результати показали упорядкованість структури поздовжніх ліній розташованих на відстані одна від одної 20-25мкм.

Наступною відібрано пробу з каналу екструдера. Проаналізувавши зразок (рис.2б), можна побачити поступове механічне руйнування структури зерна до клітинного рівня, яке відбувається внаслідок обертання шнека та виникаючих сил тертя і зсувних напружень. Зростаюча температура і тиск в каналі викликають початок виділення жирів зі структури, про що свідчать характерні невеликі краплини, та желатинізацію крохмальних зерен [23]. 


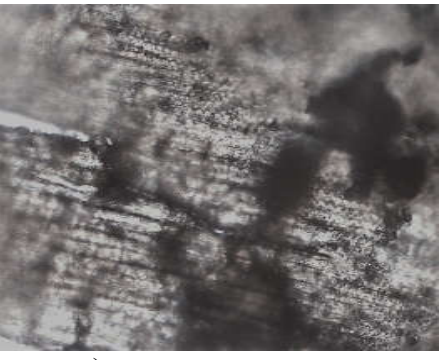

a)

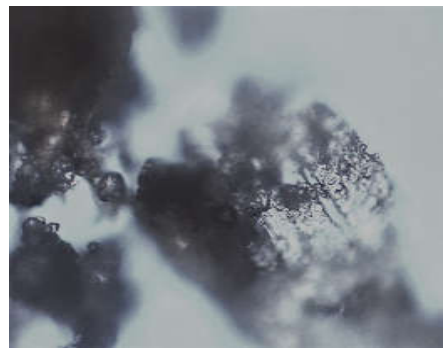

б)

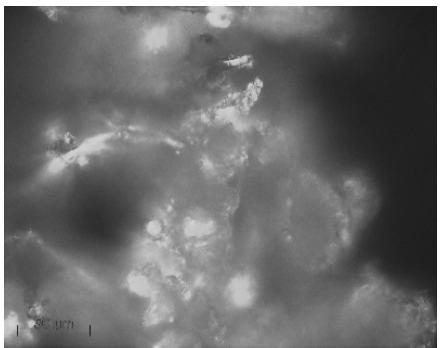

B)

а) - зразок не обробленого зерна; б) - зразок зерна відібраний з каналу шнека екструдера; в) - зразок відібраний на виході з фільєри.

\section{Рис. 2 - Зміна мікроструктури голозерного вівса в процесі екструзійної обробки}

Дослідження зразка, відібраного на виході з екструдера, також показало значну зміну у структурі (рис. 2в), у порівнянні, 3 необробленим зерном та зразком відібраним 3 каналу екструдера. Така трансформація структури пояснюється умовами, що створюються на виході з фільєри екструдера: зокрема, одночасним миттєвим перепадом тиску, температури та випаровуванням вологи. Внаслідок цього в екструдаті відбуваються значні структурні перетворення, які супроводжуються розривом стінок клітин та молекулярного ланцюга крохмалю з утворенням більш пористої структури, яка збільшується в об'ємі та, відповідно, отримує нові властивості. Окрім цього, в структурі відбувається розрив стінок жирових клітин на що вказує їх поява на зразках екструдату. При цьому завдяки короткій тривалості (6...10 с) дії високих температур, не спостерігається окислення жирів, що є безумовною перевагою даного методу [23].

Подібний характер динаміки структурних перетворень в екструдаті спостерігався і для другого режиму обробки.

Оскільки залишкова волога в екструдаті має впливати на параметри змішування компонентів сухої суміші та на термін зберігання кінцевого продукту, було проведено дослідження зміни кількості вологи в екструдаті. Результати показали, що в зразку, отриманому при початкових значеннях вологовмісту 10 \% та температурі екструзії $160{ }^{\circ} \mathrm{C}$, відбулось зменшення вологи до 5,8 \%, а в другому експерименті при початковому вологовмісті 11,8 \% та температурі екструзії $150{ }^{\circ} \mathrm{C}$ залишок вологи складає 9,4 \%. 3 двох досліджених режимів кращим є перший, оскільки, при малій кількості залишкової вологи меншим буде ризик розвитку патогенної мікрофлори, а термін зберігання таких сумішей подовжується. В подальших дослідженнях планується визначити закономірність впливу кінцевої вологи на мікрофлору та якість змішування. Відповідно такі перетворення будуть впливати на властивості кінцевого продукту і параметри змішування при одержанні сухих сумішей, що стане наступним етапом досліджень.

Висновки. В ході виконання роботи було проаналізовано стан вітчизняного ринку виробництва дієтичних харчових продуктів та визначено найбільш ефективні технології виробництва безглютенових продуктів. В якості сировини обрано перспективний вид зерна - голозерний овес, а для його обробки серед відомих технологій було обрано екструзію. Саме цей метод дозволяє сумістити в одному апараті процеси подрібнення, транспортування та термічної обробки, що відкриває можливість за рахунок регулювання параметрів процесу отримувати продукти з наперед заданими властивостями.

Проведено перший етап досліджень, який полягав у визначенні динаміки структурних перетворень в каналі екструдера та порівнянні отриманої структури екструдату з необробленим зерном. За час перебування сировини в каналі екструдера найбільш інтенсивне руйнування структури, на клітинному рівні, відбувається перед виходом з фільєри та на виході з неї, де температура, тиск, сили тертя та зсувні напруження досягають максимальних значень. Встановлено, що при початковому вологовмісті зерна 10 \%, температура процесу становить $160{ }^{\circ} \mathrm{C}$, тривалість обробки - 10с, а також спостерігається інтенсивне руйнування клітин та виділення жиру на поверхні екструдату. Підвищення початкового вологовмісту на 1,8 \% зменшує температуру процесу на $10^{\circ} \mathrm{C}$ і скорочує час обробки з 10 с до 6 с. При цьому помітно зменшуються ступінь руйнування зерна та виділення жиру, але зростає кількість залишкової вологи в зразках екструдату. Визначено, що кількість вологи в зерні перед його обробкою визначає температуру процесу, тиск, час обробки та глибину структурних перетворень в зерні. Дослідження впливу механізму екструзії на мікроструктуру показали значні відмінності у структурі до та після обробки, зокрема, утворення більш пористої структури і зниження залишкової вологи в екструдаті, що забезпечує збільшення терміну зберігання сумішей та спрощує процес перемішування сухих компонентів.

Аналіз результатів підтвердив доцільність використання екструдера для обробки голозерного вівса при отриманні сухих сумішей. Однак отримані зразки екструдату у вигляді джгуту свідчать, що екструдат необхідно буде додатково подрібнювати до консистенції борошна на млині. Наступним етапом стане вибір параметрів зміщування з іншими компонентами сухої суміші та вибір обладнання для його реалізації, а також визначення терміну зберігання продукту. 


\section{References}

1. Karpov, O. (2019). Proizvodstvo bezgliutenovoy produktsii [Production of gluten-free products.]. Foodbay Blog URL: https://foodbay.com/wiki/novosti-industrii/2019/07/10/proizvodstvo-bezglyutenovoy-produkciiproblemy-ne-zakanchivayutsya-na-recepture/

2. Naumova, O.A. (2020). Era bezgliutena: pochemu pshenichnaya muka stala vrednoy dlya boleje $10 \%$ zhytelej zemnogo shara? [The gluten-free era: why has wheat flour become harmful for more than $10 \%$ of the world's inhabitants?]. Khranenije i pererabotka zerna. Nauchno-prakticheskiy portal. https://hipzmag.com/tema/erabezglyutena-pochemu-pshenichnaya-muka-stala-vrednoj-dlya-bolee-10-zhitelej-zemnogo-shara/

3. Mukoid, R., Yemel'yanova, N., Ukrainets, A., Chumakova, O., Svydynyuk, I. (2010). Oves golozerny syrovyna dlia likuval'no-dietychnykh produktiv [Naked oats - raw materials for therapeutic dietary products]. Kharchova ta pererobna promyslovist, 2, 24-25 (in Ukrainian).

4. Andrejev, N.R., Goldshtejn, V.G., Nosovskaya, L.P., Adikajeva, L.V., Golionko, Ye.O. (2019.) Golozerny oves - perspektivnoje syr'yo dlya glubokoy pererabotki [Naked oats are a promising raw material for deep processing]. Agroculture Science Euro-North-East, 20(5), 447-455 (in Russian).

5. Koshova, V.M., Mukoid, R., Gurina, J.J., Ushach, A.V. (2016). Kharakterystyka ryznykh sortiv vivsa [Characteristics of different varieties of oats]. Naukovi Praci NUKhT, Kyiv, 22(2), 213-219 (in Ukrainian).

6. Valentine, J., Clothier, R.B. (1992) The development of naked oats in the UK. The changing role of oats in human and animal nutrition. Proceed. of the IV Intern. oat conference. Adelaide, South Australia, 38-41.

7. Buranova, S.V. (2010). Tekhnologichni vlastyvosti golozernogo vivsa ta metody jogo zberigannya [Technological properties of Naked Oats and methods of its storage]. Avtoref. dis. kand. techn. nauk, 05.18.01, Odessa, ONAKhT, 22 (in Ukrainian).

8. Sots, S.M., Kustov, I.O. (2015). Osoblyvosti tekhnologichnykh vlactyvostej ta khimichnogo skladu golozernogo vivsa sortu «salomon» [Features of technological properties and chemical composition of Naked Oats of the Salomon variety]. Kharchova nauka i tekhnologiya, 2(31), 103-108 (in Ukrainian).

9. Sots, S., Chumachenko, Yu., Kustov, I. \& Kuz'menko, Yu. (2020). Zerno golozernogo vivsa ta golozernogo yachmeniu. Osoblyvosti tekhnologichnykh vlastyvostej zerna [Grain of Naked Oats and naked barley. Features of technological properties of grain]. Scientific Works, 84(2), 5-9 (in Ukrainian).

10. Welch, R.W. (1995). The Oat Crop: Production and Utilization. ed. Chapman and Hall, UK. 584.

11. Kasjanova, L.A., Baitova, S.N. (2007). Otsenka kachestva zerna golozernogo i pljonchatogo ovsa kak syr'ya dlya proizvodstva pishchevykh produktov[Evaluation of the quality of grain of naked and filmy oats as raw materials for food production]. Vestnik Mogilyovskogo gos. un-ta prodovol'stviya, 1, 37-41 (in Russian).

12. Mazurkak, I.V., Likhochvor, V.V., Mazurkak, O.T. (2019). Vliyaniye norm posieva na urozhajnost i kachestvo zerna ovsa $\mathrm{v}$ usloviyakh zapadnoj liesostiepi Ukrainy[The influence of sowing norms on the yield and quality of oat grain in the conditions of the western forest-steppe of Ukraine]. Vestnik BGSKhA -nauchnometodicheski zhurnal, Gorki, Bielorus', 2, 94-96 (in Russian).

13. Sots, S.M., Voloshenko, O.S., Kustov, I.O. (2013). Vplyv vodoteplovoj obrobky zerna na vykhid i yakist' tsiloi krupy z golozernogo vivsa [Influence of water heat treatment of grain on the yield and quality of whole grains from Naked Oats]. Naukovi pratsi ONAKhT, 44 (1), 7-10 (in Ukrainian).

14. Yanova, M.A., Ivanova, T.S. (2014). Ekstrusionnaya obrabotka zerna yachmenia i ovsa dlya polucheniya muki $i$ muchnykh konditerskikh khliebobulochnykh izdeliy [Extrusion processing of barley and oat grains for the production of flour and flour confectionery, bakery products]. Krasnoyarsk, 115 (in Russian).

15. Yur'yev, V.P., Bogatyrev, A.N. (1991). Fiziko-khimicheskiye osnovy polucheniya ekstruzionnykh produktov na osnovie rastitiel'nogo syr'ya [Physico-chemical bases of obtaining extrusion products based on vegetable raw materials]. Vestnik siel'khoz. nauki, 12, 43-51 (in Russian).

16. Shaburova, G.V. (2012). Ekstrudirovanny yachmien' kak component funktsional'nych pishchevykh produktov [Extruded barley as a component of functional food products]. Pishchevaya promyshlennost. 10, 44-45 (in Russian).

17. Magomedov, G.O., Karpenko, V.I., Zhuravliov, A.A. (2010). Reologicheskiye svojstva tiestsa s ekstrudatom ovsa [Rheological properties of the dough with oat extrudate]. Khranieniye i pererabotka sel'khoz. syr'ya. 11, 27-29 (in Russian).

18. Chekina, M.S. (2017). Pazrabotka tekhnologii zernovykh siropov iz golozernykh sortov ovsa [Development of technology of grain syrups from naked varieties of oats]. Dis. kand. techn. nauk, 05.18.07, SPb, SPb NIU ITMO, 165 (in Russian).

19. Bykovskaya, G. (1992). Ekstrusionnaya tekhnologiya v Yaponii [Extrusion technology in Japan]. Khlieprodukty, 7, 50-53 (in Russian).

20. Extrusion cooking technology/ Ed. R. Sowitt (1984). London; New York, 212 p

21. Bailey, L.N., Hauck, B. W., Sevatson, E.S., Singe,r R.E. (1991). Systems for manufacture of ready to eat breakfast cereals using twin-screw extrusion. Cereal Foods World, 10, 863-869.

22. Ivanitsky, G.K., Shurchkova ,Yu.A., Radchenko, N.L. (2011). Modelirovaniye protsessa ekstruzii v predmatrichnoj zonie i v matritse pri obrabotkie rastitel'nogo syr'ya [Modeling of the extrusion process in the 
pre-matrix zone and in the matrix during the processing of plant raw materials]. Promyshlen. teplotekhnika, 33 (6) 32-38 (in Russian).

23. Ostrikov, A.N., Abramov, O.V., Rudometkin, A.S. (2004). Ekstrusiya v pishchevykh tekhnologiyakh [Extrusion in food technologies]. SPb, GIORD (in Russian).

\title{
PROSPECTS OF USING NAKED OATS IN GLUTEN-FREE DIETARY PRODUCTS. EXPERIMENTAL INVESTIGATION OF THE GRAIN STRUCTURE CHANGES DURING EXTRUSION PROCESSING
}

\author{
Ivanitsky G.K., Dr. Sci. Tech., Tselen B.Ya., Ph.D., Ganzenko V.V., Ph.D., Radchenko N.L., Ph.D. \\ Institute of Engineering Thermophysics of NAS of Ukraine, Kyiv
}

\begin{abstract}
In the article the analysis of the world and domestic market of manufacture products gluten-free was carried. We have identified the need to develop this area in the context of the annual increase in the number of people who are unable to digest gluten protein. In Ukraine own manufacture of products without gluten is still limited, and the basic assortment of these products is delivered from other countries. The primary goals have been as a result formulated. They provide, first of all, the need to increase their own production volumes through the search for new types of raw materials, recipes and the development of new processing technologies. In solving these problems, we analyzed various types of raw materials, from which naked oats were selected as the main component of dry dietary gluten-free mixtures. For its processing, it was proposed to use a screw extruder, since it allows, by regulating the initial moisture in the grain, to change the pressure, process temperature and processing time, thus predicting the necessary microstructure of the extrudate and properties. In addition, during extrusion, harmful microflora is neutralized and excess moisture is removed, which will increase the shelf life of the dry mix and improve the quality of mixing the components. Experimental studies were carried out in order to confirm the feasibility of using an extruder for processing naked oats and obtaining dry powder mixtures. In the course of the study, the structure of the extrudate was compared with the internal structure of the whole grain, due to which the dynamics of the structural transformations of the product that occur in the extruder channel was analyzed, as well as the factors of the influence of extrusion on the microstructure of grain under various processing modes were established. The amount of residual moisture in the resulting extrudate was found to determine further shelf life of dry mixtures and mixing parameters with other components. As a result, the expediency of using an extruder for processing naked oats in the production of dry mixtures has been proven.
\end{abstract}

Key words: naked oats, gluten-free products, extrusion technology, extruder.

\section{Список використаної літератури}

1. Производство безглютеновой продукции. Foodbay Blog: веб-сайт. URL: https://foodbay.com/wiki/novostiindustrii/2019/07/10/proizvodstvo-bezglyutenovoy-produkcii-problemy-ne-zakanchivayutsya-na-recepture/ (дата звернення 23.02.2021).

2. Эра безглютена: почему пшеничная мука стала вредной для более $10 \%$ жителей земного шара? Хранение и переработка зерна. Научно-практический портал: веб-сайт. URL: https://hipzmag.com/tema/erabezglyutena-pochemu-pshenichnaya-muka-stala-vrednoj-dlya-bolee-10-zhitelej-zemnogo-shara/__дата звернення 23.02.2021).

3. Мукоїд Р., Смельянова Н., Українець А., Чумакова О., Свидинюк І. Овес голозерний - сировина для лікувальнодієтичних продуктів. Харчова та переробна промисловість. 2010. № 2. С. 24-25.

4. Андреев Н.Р., Гольдштейн В.Г., Носовская Л.П., Адикаева Л.В., Голионко Е.О. Голозерный овес - перспективное сырье для глубокой переработки. Agroculture Science Euro-North-East. 2019. № 20(5). С. $447-455$.

5. Кошова В.М., Мукоїд Р.М., Гуріна О.О., Усач А.В. Характеристика різних сортів вівса Наукові праці НУXT. 2016. № 22(2). С. 213-219.

6. Valentine J., Clothier R.B. The development of naked oats in the UK. The changing role of oats in human and animal nutrition. Proceedings of the IV International oat conference. Adelaide, South Australia. 1992. P. 3841.

7. Буранова С.В. Технологічні властивості голозерного вівса та методи його зберігання: автореф. дис. на здобуття наук. ступеня к. т. н. : 05.18.01. Одеса, 2010. 20 с.

8. Соц С.М., Кустов І.О. Особливості технологічних властивостей та хімічного складу голозерного вівса сорту «саломон». Харчова наука і технологія. 2015. №2(31). С. 103-108.

9. Соц С., Чумаченко Ю., Кустов І., Кузьменко Ю. Зерно голозерного вівса та голозерного ячменю. Особливості технологічних властивостей зерна. Scientific Works. №84(2). С. 5-9.

10. Welch R.W. The chemical composition of oats. The Oat Crop: Production and Utilization. ed. Chapman and Hall. 1995. P. 279-320. 
11. Касьянова Л.А., Баитова С.Н. Оценка качества зерна голозёрного и плёнчатого овса как сырья для производства пищевых продуктов. Вестник Могилевского гос. университета продовольствия. 2007 . № 1. С. 37-41.

12. Мазурак И. В. Лихочвор В.В., Мазурак О.Т. Влияние норм посева на урожайность и качество зерна овса в условиях западной лесостепи Украины. Вестник БГСХА: науч.-метод. журн. 2019. № 2. С. 94 96.

13. Соц С.М., Волошенко О.С., Кустов І.О. Вплив воднотеплової обробки зерна на вихід і якість цілої крупи з голозерного вівса. Наукові пращчі ОНАХТ. 2013. № 44 (1). С. 7-10.

14. Янова М.А., Иванова Т.С. Экструзионная обработка зерна ячменя и овса для получения муки и мучных кондитерских, хлебобулочных изделий. Красноярск: Краснояр. гос. аграр. ун-т, 2014. 115 с. URL: http://www.kgau.ru/sveden/2017/ipp/metod_190402_ukp_17.pdf (дата звернення 15.03.2021).

15. Юрьев В.П., Богатырев А.Н. Физико-химические основы получения экструзионных продуктов на основе растительного сырья. Вестник сельхоз науки. 1991. № 12. С. 43-51.

16. Шабурова Г.В. Экструдированный ячмень как компонент функциональных пищевых продуктов. Пищевая промышленность. 2012. № 10. С. 44-45.

17. Магомедов Г.О., Карпенко В.И., Журавлев А.А. Реологические свойства теста с экструдатом овса. Хранение и переработка сельхозсырья. 2010. № 11. С. 27-29.

18. Чекина М.С. Разработка технологии зерновых сиропов из голозерных сортов овса: автореф. дис. на соиск. науч. степени к. т. н. : 05.18.07. Санкт-Петербург, 2017. 16 с.

19. Быковская Г. Экструзионная технология в Японии. Хлебопродуктыл. 1992. № 7. С. $50-53$.

20. Sowitt R. Extrusion cooking technology. London. New York, 1984. 212 p.

21. Bailey L.N., Hauck B. W., Sevatson E.S., Singer R.E. Systems for manufacture of ready-to-eat breakfast cereals using twin-screw extrusion. Cereal Foods World. 1991. № 10. C. 863-869.

22. Иваницкий Г.К., Шурчкова Ю.А., Радченко Н.Л. Моделирование процесса экструзии в предматричной зоне и в матрице при обработке растительного сырья. Промышленная теплотехника. 2011 . № 33 (6). С. 32-38.

23. Остриков А.Н., Абрамов О.В., Рудометкин А.С. Экструзия в пищевых технологиях.СПб.: ГИОРД, 2004. $288 \mathrm{c}$.

Отримано в редакцію 01.04.2021

Прийнято до друку 02.07.2021
Received 01.04.2021

Approved 02.07.2021 